\title{
ПІДВИЩЕННЯ СТІЙКОСТІ БУДІВЕЛЬНИХ ВИРОБІВ ПРИ МАЛОЦИКЛОВІЙ УТОМІ БЕТОНУ
}

\section{INCREASE RESISTANCE OF BUILDING CONSTRUCTIONS AT LOW CYCLE FATIGUE OF CONCRETE}

Коробко О.О., к.т.н., доц., Вировой В.М., д.Т.н., проф., Уразманова Н.Ф., аспірант, Непомнящий О.М., асистент (Одеська державна академія будівництва та архітектури, м. Одеса)

Korobko O. O., candidate of technical sciences, docent, Vyrovoy V.M., doctor of technical sciences, professor, Urazmanova N. F., post-graduate student, Nepomnyashchy O. M., assistant (Odessa State Academy Civil Engineering and Architecture, Odessa)

Підвищити стійкість будівельних виробів можна за рахунок формування взаємозалежних різномасштабних структур для одержання заданого набору різних за призначенням структурних елементів, що гарантують безпеку функціонування бетону в складних умовах експлуатації.

Structural adaptation of the material provides stability of initial level of properties of concrete under the influence of changing stress. This is, to a large extent, determined by changes the parameters of technological cracks and inner surfaces of partition as active elements of the structure, capable in a timely manner of responding to external influences. Material properties remain at the predetermined level as result of structure self-organization. Poly-structure of concretes implies mutual influence and interaction of the structural levels at all periods of their life cycle. There are new possibilities for the directed organization of the structure of concrete as a complex dynamic open system by changing the initial conditions for the structure formation of individual subsystems - the levels of structural heterogeneities. Variation of the compositions can serve as a factor of controlling the kinetics of the processes of organization of the structure at a certain level with reaching the level of the structure of the concrete and the product. The microstructure of concrete can be organized by internal, external and complex activation. The operating factor of macrostructure formation can be a change in the ratio of adhesion and cohesive bonding forces at the surface of partition between the matrix material and the fillers. Concretes with a structure formed by selective adhesion of the cement matrix to the fillers had the raised parameters of quality and were better adapted to low-cycle fatigue stress. Interference and interaction of the active elements of the structure is a factor of the safe 
functioning of building constructions. To increase the resistance of concretes can be due to the directional formation of interdependent structures. It allows you to obtain the specified sets of structural elements that ensure the preservation of the level of the product properties in complex operating conditions.

Ключові слова: бетон, керамзитобетон, структура, самоорганізація, активні елементи, деформації, пошкодженість, малоциклова утома.

Concrete, expanded clay concrete, structure, self-organization, active elements, deformations, damage, low cycle fatigue.

Вступ. Будівельні конструкції та вироби експлуатуються переважно в умовах середовища, яке безперервно змінює температурні та вологісні параметри. Для безпеки функціонування конструкцій і виробів структура матеріалу має включати набори елементів, що здатні своєчасно реагувати на поперемінні впливи зовнішніх факторів. Такими елементами виступають технологічні та експлуатаційні тріщини і внутрішні поверхні розділу (ВПР), які присутні на всіх рівнях структурних неоднорідностей будь-якого композиційного матеріалу та визначають, в якості активних елементів, стійкість конструкцій і виробів при періодичних циклах заморожуваннявідтавання та зволоження-висушування [1]. Поліструктурність бетону передбачає співіснування ієрархії взаємно підпорядкованих різномасштабних рівнів структури, зв'язаних через поверхні розділу в єдину дисипативну систему [2, 3]. На кожному окремому рівні утворюються індивідуальні набори тріщин і ВПР, які є невід'ємними складовими загальної складно організованої сітки активних елементів на рівні виробу (конструкції). Неоднорідності як підсистеми з характерними лише для них складовими можуть впливати одна на одну при організації інтегральної структури бетонусистеми. Для одержання заданих наборів різнорівневих тріщин і внутрішніх поверхонь розділу раціональним підходом прийнято регулювання різноманіттям взаємозалежних підструктур бетону. Це дозволить виявити шляхи вирішення проблеми підвищення стійкості будівельних виробів при малоцикловій утомі матеріалу.

Аналіз останніх досліджень. Проведений огляд науково-технічної інформації дозволив проаналізувати характерні особливості структуроутворення бетону як поліструктурного матеріалу [2], доцільність використання структурного (системного) підходу в будівельному матеріалознавстві [4, 5], умови розвитку деформацій різних видів, що супроводжують процеси тверднення композиційних матеріалів, різноманітні умови експлуатації та способи захисту виробів і конструкцій. Це послужило базою для обгрунтування необхідності подання будівельного виробу як об’єкту-системи зі специфічним оформленням структури. 
Постановка мети та задачі досліджень. Мета досліджень - підвищити стійкість бетонів на щільних $\mathrm{i}$ пористих заповнювачах за рахунок направленого формування різних за вилом та призначенням взаємозалежних підструктур для одержання заданих наборів структурних елементів, що забезпечують збереження проектного рівня властивостей виробу в умовах експлуатації, пов'язаних 3 багаторазовими циклами заморожуваннявідтавання та зволоження-висушування.

Задачі досліджень: - проаналізувати взаємовплив рівнів структурних неоднорідностей бетону та виявити фактори направленої організації мікро-та макроструктур; - визначити динаміку зміни структури та властивостей бетону і керамзитобетону при малоцикловій утомі та тривалому твердненні.

Методика досліджень. Дослідження проводили на: на моделях чарунок 3 різним орієнтуванням імітаторів заповнювачів в цементній матриці; зразкахкубах розміром $100 \times 100 \times 100$ мм, виготовлених з бетону і керамзитобетону на заповнювачах з різним станом поверхні. Моделі структурних чарунок були виготовлені на основі цементного тіста і полімервміщуючих композитів. Розташування імітаторів-призм забезпечило одержання чарунок кубічної та гексагональної форм. Кожна модель включала по три чарунки з різним орієнтуванням імітаторів один відносно одного.

Пошкодженість матричного матеріалу оцінювали через коефіцієнт, який визначається як співвідношення сумарної протяжності технологічних тріщин і внутрішніх поверхонь розділу на виділеній поверхні зразка [6].

Показники міцності на стиск, модуля пружності, відкритої пористості, середньої густини, водопоглинання та маси бетонних зразків до та після кожного циклу періодичних температурних і вологісних впливів визначали за стандартними методиками. На основі одержаних значень різних властивостей були обчислені коефіцієнти стійкості бетону i керамзитобетону при малоцикловій утомі як співвідношення показника властивості бетонів після певної кількості циклів впливу до показника властивості бетонів після 28 діб нормального тверднення.

Результати досліджень. Запропоновані теоретичні положення та експериментальні результати базуються на робочій гіпотезі, що уявлення будівельних виробів як системи, що самоорганізується, та є відкритою до зовнішніх чинників, дасть змогу визначити фактори направленого формування взаємозв'язаних різнорівневих структур бетону.

Будівельні вироби та бетон як матеріал, з якого їх виготовлено, являють собою певну системну спільність. Взаємозв'язок матеріалу та виробу передбачає, що структура бетону визначає структурне оформлення виробу як системи, яка включає бетон в якості складової частини (підсистеми). В свою чергу, бетон розглядається як матеріал, організований у вигляді сукупності взаємозалежних структурних неоднорідностей на рівнях: часток в'яжучого (мікроструктура); продуктів новоутворень (наноструктура), взаємодії 
матричного матеріалу i заповнювачів (макроструктура) та виробу як спеціально оформленого матеріалу конкретної геометричної форми. На кожному рівні неоднорідностей утворюється набір характерних структурних елементів. Зроблено припущення, що зміна складів вихідних компонентів може служити фактором керування кінетикою процесів організації структури на тому чи іншому рівні з виходом на рівень структури бетону та виробу. Всі рівні структурних неоднорідностей виробу, включаючи сам виріб, $\epsilon$ відкритими складними системами, що самоорганізуються в аутопоезісному режимі [7]. Подібний порядок структуроутворення передбачає певну вибірковість організації системи при збереженні іiі відкритості до впливу навколишнього середовища.

Механізми організації структури виділених рівнів неоднорідностей якісно відрізняються. На кожному рівні реалізується свій комплекс процесів та явищ, що визначають їх фінальний стан. Проте, всі неоднорідності знаходяться в різномасштабній підпорядкованості та впливають один на одного, викликаючи взаємозалежні структурні зміни, чим підтримується самоорганізація структури протягом всього життєвого циклу матеріалу.

3 різних початкових положень при різних умовах структуроутворення на всіх рівнях неоднорідностей виникають однакові за типом елементи структури - поверхні розділу. Завдяки поверхням розділу стає можливою передача різного виду деформацій між складовими одного рівня та складовими, що належать різним рівням неоднорідностей. Таким чином, деформації в якості елементу визначають процеси структуроутворення та функціонування бетону. Керування проявом деформацій в початковий період дозволяє направлено забезпечити структуру матеріалу та, в першу чергу, впливати на формування полів залишкових деформацій та зародження технологічних тріщин i внутрішніх поверхонь розділу. Для одержання заданих наборів активних елементів прийняті фактори керування процесами організації мікро- та макроструктур бетону.

В якості мікроструктури бетону виділено рівень часток в'яжучого, який можна представити як грубодисперсну висококонцентровану ліофобну систему з ліофільною границею розділу фаз [8]. Характерними елементами цього рівня $є$ періодично організовані кластерні структури 3 дисперсних часток. Кластери утворюються в результаті неврівноважених міжчасткових взаємодій і обмінних процесів та взаємодіють між собою з утворенням міжкластерних поверхонь розділу, які $\epsilon$ потенційними зародковими тріщинами. Організовувати структуру мікрорівня неоднорідностей можна через способи внутрішньої, зовнішньої та комплексної активації твердіючих систем. На зміну вихідних умов мікроструктура бетону як відкрита системи, що самоорганізується, реагує перерозподілом неврівноважених сил міжчасткових взаємодій та утворенням структурних агрегатів 3 іншими параметрами. Для підтвердження цього були виконані експерименти на 
моделях дисперсних ліофобних систем. Результати досліджень показали, що площа та протяжність зовнішніх границь складових неактивованих та активованих систем відрізнялися до 3,5-5 разів при суттєвій зміні форми агрегатів та періодів їх формування. Аналогічний вплив видів активації спостерігається на цементно-водних та полімервміщуючих композиціях.

Зміна початкової структури, що визначається параметрами поверхонь розділу та умовами міжфазних взаємодій, веде до зміни величини і кінетики прояву об'ємних деформацій та строків тужавлення систем на основі мінеральних або органічних в'яжучих. При активації систем на мінеральних в'яжучих показники об'ємних деформацій змінювалися до 2-7 разів, строки тужавлення до 120 хв. Об'ємні деформації полімерних композицій залежно від способу активації відрізнялись за величиною та інтенсивністю прояву до 2,5-4,5 разів, періоди формування структури на 30-180 хв. Зміна властивостей матеріалів, що твердіють, $є$ своєрідним відображенням зміни умов їх структуроутворення. Показова відмінність кінцевих структур позначилась на технологічній пошкодженості, тріщиностійкості, міцності при стиску та згині цементно-водних і полімервміщуючих композитів, а також модулі пружності затверділих полімерних зразків та глибині карбонізації цементного каменя. Вид активації забезпечує структури, що ведуть до підвищення значень властивостей матеріалів при зменшенні витрат цементу до 35\% чи епоксидної смоли до 65\%. Були визначені склади в'яжучого, що дозволяють одержувати композити 3 поліпшеними показниками якості. Більш ефективною $\epsilon$ комплексна активація з використанням полімінеральних і полідисперсних наповнювачів.

В бетонах мікроструктура $є$ матричною складовою макроструктури, тому умови іï структурної організації визначаються зміною оформлення макрорівня неоднорідностей. Вихідні параметри макроструктури в значній мірі залежать від складів заповнювачів, які були виділені в якості факторів регулювання різномасштабним структуроутворенням бетону. Заповнювачі в матричному матеріалі утворюють набори своєрідних упорядкованих чарунок, що $є$ характерними елементами макроструктури. Навіть при одному й тому ж складі бетону співіснують чарунки різних форм та розмірів. Організація структури матричного матеріалу відбувається одночасно в усіх чарунках, проте ії реалізація індивідуальна для кожної окремої чарунки (рис. 1).

На моделях чарунок було визначено, що залежно від розташування та стану поверхні заповнювачів в цементної або полімерної матриці утворюються структури, що відрізняються конфігурацією, площею та густиною, а також протяжністю границь розділу при неповторності формування полів залишкових деформацій в окремих чарунках. Це привело до зміни об'ємних деформацій, на 28-45\% та строків тужавлення цементного тіста до 150 хв. 


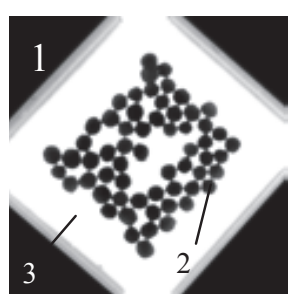

$\mathrm{L}=38,1 \mathrm{~cm}$; $\mathrm{S}=45,4 \mathrm{~cm}^{2}$

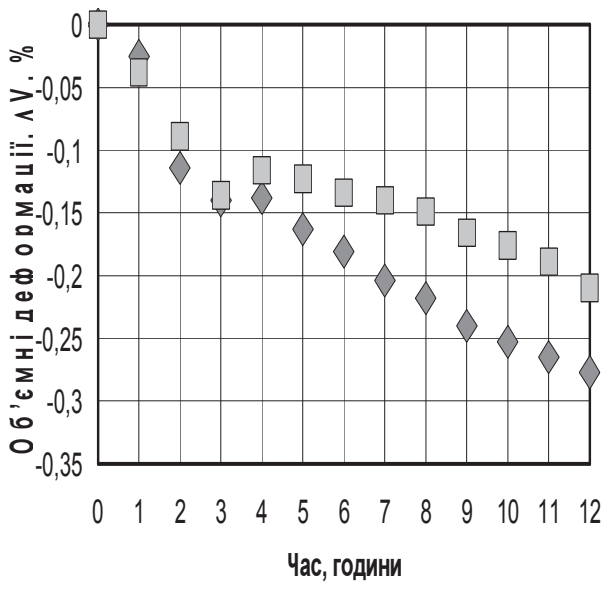

б) $\mathrm{S}=42,7 \mathrm{~cm}^{2}$

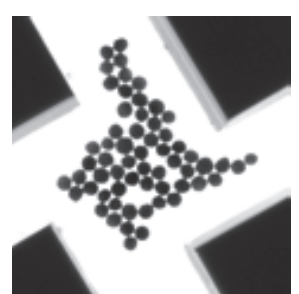

$\mathrm{L}=55,7 \mathrm{~cm}$; $\mathrm{S}=58,7 \mathrm{~cm}^{2}$

a)

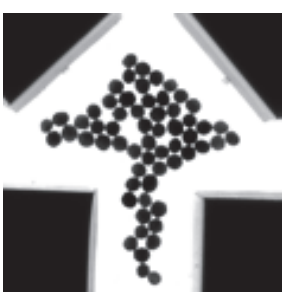

$\mathrm{L}=62,9 \mathrm{~cm}$;

$\mathrm{S}=66,1 \mathrm{~cm}^{2}$
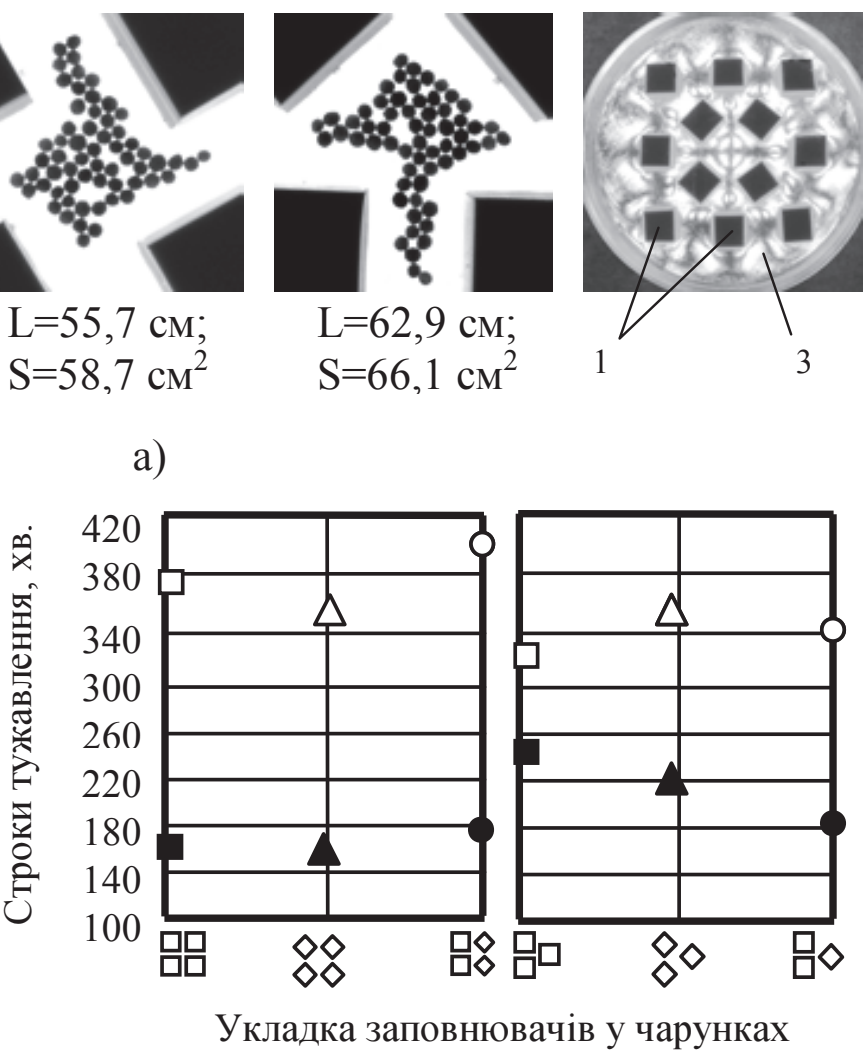

B)

Рис.1. Структуроутворення та прояв властивостей матричного матеріалу в структурних чарунках різних форм:

a) організація структури матричної складової (1 - імітатори заповнювачів, 2 - частки дисперсної фази, 3 - епоксидна смола як дисперсійне середовище);

$\mathrm{L}$ - протяжність зовнішніх границь кластерів; S - площа кластерів;

б) об’ємні деформації матричного матеріалу, що твердіє ( $\diamond$ - кубічна укладка заповнювачів, $\square-$ гексагональна укладка заповнювачів);

в) строки тужавлення матричного матеріалу

$(\boldsymbol{\bullet}, \boldsymbol{\Lambda}, \bullet-$ початок, хв., $\square, \boldsymbol{\Delta}, \circ-$ кінець, хв.).

Величина коефіцієнту пошкодженості цементного каменя відрізнялася до 2,5 разів, показники водопоглинання зразків до 40\%, міцності при стиску до 2 разів. Розвиток магістральної тріщини визначався розподілом чарунок в моделях та проходив по початковим активним елементам.

Бетони промислових складів включають багатоваріантні за геометричними параметрами набори структурних чарунок із заданими умовами взаємодії матриці 3 поверхнею заповнювачів. Збільшити різноманітність параметрів чарунок можна за рахунок зміни співвідношення адгезійно-когезійних сил зв'язку на границі розділу між матрицею та заповнювачами. Чарунки являють собою відносно автономні частини бетону, в яких забезпечуються набори структурних складових, що через взаємовплив визначають потенціал структури та рівень властивостей всього матеріалу до експлуатації. Були забезпечені характерні випадки міжфазних взаємодій 3 повною, недосконалою та 
вибірковою адгезією матриці до поверхні заповнювачів. Поверхню частини зерен гранітного щебеня та керамзитового гравію апретували ГКР-11. В результаті був одержаний важкий бетон трьох класів та керамзитобетон двох класів з відповідним рівнем властивостей. Поліпшеними показниками відрізнялися бетони, структура яких була ініційована вибірковою адгезією матриці до поверхні заповнювачів.

Позитивний ефект структурного різноманіття зберігався при експлуатації будівельних композитів. Враховуючи, що тріщини i внутрішні поверхні розділу співіснують на всіх рівнях структурних неоднорідностей, структуру бетону можна уявити як різномасштабну сітку активних елементів. Завдяки сітковій взаєзмозв'язаності підструктур градієнти екзо- і ендодеформацій [9] передаються з одного рівня неоднорідностей на інший та перерозподіляються між ними. Самозбереження рівнів забезпечується локалізацією росту тріщин всередині неоднорідностей, що запобігає їх злиттю в тріщини руйнування. Сприятливі структурні зміни, пов'язані із саморозвитком сітки тріщин i внутрішніх поверхонь розділу, дають змогу проявитися різним механізмам адаптації для підтримки властивостей композитів на початковому рівні.

Для підтвердження цього були визначені коефіцієнти стійкості бетонів при періодичних зволоженні-висушуванні та заморожуванні-відтаванні. До температурних і вологісних впливів краще пристосовувалися бетони, що включали більш різноманітні за властивостями набори чарунок. Крім того, початкова структура спадково впливала на зміну властивостей будівельних композитів при тривалому твердненні. Зміна пошкодженості, полімерних композицій, цементного каменя та бетонів у часі свідчить про безперервність структурних перебудов, завдяки яким властивості матеріалів підтримуються на рівні, не нижче проектного. Регулювання структурним різноманіттям дозволило отримати структури 3 заданим комплексом складових, що позначилося на рівні фізико-технічних властивостей матеріалу.

Висновки. Теоретично обгрунтовано та експериментально підтверджено, що бетон являє собою цілісність, утворену різними підструктурами. Результати досліджень композитів на різного виду в'яжучих показали, що структурні зміни матеріалу відбуваються в рамках резерву різноманіття структур. Стійкість матеріалів залежить від забезпечення цього резерву. Ця передумова послужила базою при визначенні складів та технології виготовлення виробів на основі цементних и полімерних композицій та бетонів. Уявлення будівельних виробів як відкритих систем, що самоорганізуються, дозволило одержати матеріали з заданими наборами структурних елементів та властивостей за рахунок направленої організації їх різномасштабної структури. Отримані матеріали відзначалися підвищеною стійкістю в умовах експлуатації, зокрема, при тривалому твердінні та малоцикловій утомі. 
1. Суханов В.Г. Структура материала в структуре конструкции / В.Г. Суханов, В.Н. Выровой, О.А. Коробко. - Одесса: «ПОЛИГРАФ», 2016. - 244 с.

2. Соломатов В.И. Полиструктурная теория композиционных строительных материалов / [В.И. Соломатов, В.Н. Выровой и др.]. - Ташкент: ФАН, 1991. - 345 с.

3. Коробко О.А. Роль деформаций в «жизни» бетона / О.А. Коробко, В.Г. Суханов, В.Н. Выровой, В.Ю. Тофанило // Известия КГАСУ. - 2014. - № 3 (29). - С. 114-121.

4. Прангишвили И.В. Системный подход и общесистемные закономерности / И.В. Прангишвили. - М.: «СИНТЕГ», 2000. - 519 с.

5. Выровой В.Н. Системный подход при анализе структуры строительных композиций / В.Н. Выровой, В.С. Дорофеев, В.Г. Суханов // Зб. наук. пр. «Ресурсоекономні матеріали, конструкції, будівлі та споруди». - 2008. - Вип. 16. - Ч. 1. - С. 133-139.

6. Выровой В.Н. Композиционные строительные материалы и конструкции. Структура, самоорганизация, свойства / В.Н. Выровой, В.С. Дорофеев, В.Г. Суханов. - Одесса: «ТЭС», 2010. - 169 с.

7. Коробко О.А. Бетон как самоорганизующаяся система / О.А. Коробко, В.Н. Выровой, В.Г. Суханов, В.Ю. Тофанило // Вісник ОДАБА. - 2014. - Вип. 53. - С. 182190.

8. Композиционные строительные материалы и конструкции пониженной материалоемкости / В.И. Соломатов и др. - К.: Будівельник, 1991. - 144 с.

9. Коробко О.А. Роль эндо- и экзодеформации в организации структуры бетона / О.А. Коробко, В.Ю. Тофанило, В.Н. Выровой // Зб. наук. пр. «Ресурсоекономні матеріали, конструкції, будівлі та споруди». - 2014. - Вип. 29. - С. 30-36.

1. Suhanov V.G. Struktura materiala v strukture konstrukcii / V.G. Suhanov, V.N. Vyrovoj, O.A. Korobko. - Odessa: «POLIGRAF», 2016. - 244 s.

2. Solomatov V.I. Polistrukturnaya teoriya kompozicionnyh stroitel'nyh materialov / [V.I. Solomatov, V.N. Vyrovoj i dr.]. - Tashkent: FAN, 1991. - 345 s.

3. Korobko O.A. Rol' deformacij v «zhizni» betona / O.A. Korobko, V.G. Suhanov, V.N. Vyrovoj, V.YU. Tofanilo // Izvestiya KGASU. - 2014. - № 3 (29). - S. 114-121.

4. Prangishvili I.V. Sistemnyj podhod i obshchesistemnye zakonomernosti / I.V. Prangishvili. - M.: «SINTEG», 2000. - 519s.

5. Vyrovoj V.N. Sistemnyj podhod pri analize struktury stroitel'nyh kompozicij / V.N. Vyrovoj, V.S. Dorofeev, V.G. Suhanov// Zb. nauk. pr. «Resursoekonomni materialy", konstrukciyi, budivli ta sporudy'». - 2008. - Vy’p. 16. - Ch. 1. - S. 133-139.

6. Vyrovoj V.N. Kompozicionnye stroitel'nye materialy i konstrukcii. Struktura, samoorganizaciya, svojstva / V.N. Vyrovoj, V.S. Dorofeev, V.G. Suhanov. - Odessa: «TES», 2010. - 169 s.

7. Korobko O.A. Beton kak samoorganizuyushchayasya sistema / O.A. Korobko, V.N. Vyrovoj, V.G. Suhanov, V.YU. Tofanilo // Visny`k ODABA. - 2014. - Vy`p. 53. - S. $182-$ 190.

8. Kompozicionnye stroitel'nye materialy i konstrukcii ponizhennoj materialoemkosti / V.I. Solomatov i dr. - K.: Budivel'nik, 1991. - 144 s.

9. Korobko O.A. Rol' ehndo- i ehkzodeformacii v organizacii struktury betona / O.A. Korobko, V.Yu. Tofanilo, V.N. Vyrovoj // Zb. nauk. pr. «Resursoekonomni materialy", konstrukciyi, budivli ta sporudy`». - 2014. - Vy`p. 29. - S. 30-36. 